\title{
Research on Academic Information System Unnes Using Technology Acceptance Model (TAM)
}

\section{Wahyu Hardyanto ${ }^{1}$, Sugiyanto ${ }^{1}$, Aji Purwinarko², and Aryono Adhi}

${ }^{1}$ Physics Department Faculty of Math and Science Semarang State University

${ }^{2}$ Computer Science Department Faculty of Math and Science Semarang State University

\section{Abstract}

Online assessment has been carried out research on academic information system Unnes using Technology Acceptance Model (TAM) whose goal is to achieve accountability in academic application by taking the Graduate Program Unnes sampling. The method used to carry out this research through interviews/in dept interviews, documentation and questionnaires. Analyses were performed using analysis of Structural Equation Modeling (SEM) based covariance AMOS (Analysis of Moment Structures). The results obtained overall, Knowledge of Search Domain has no effect on Perceived Ease of Use. However, CMIN / DF qualified, because it has a value of $\leq 2$.

Keywords: Academic Information System, TAM, SEM
Received: 21 May 2019

Accepted: 26 June 2019

Published: 7 July 2019

Publishing services provided by Knowledge E

(c) Wahyu Hardyanto et al. This article is distributed under the terms of the Creative Commons Attribution License, which permits unrestricted use and redistribution provided that the original author and source are credited.

Selection and Peer-review under the responsibility of the UICRIC Conference Committee.

\section{G OPEN ACCESS}

\section{Introduction}

Management of educational process can be performed using academic information systems utilize information technology. Suppose that in the process of admission, and teaching and learning activities, and management of graduation

Unnes is one of the university has been developing Integrated Academic Information System based on information technology require academic justification. This research was conducted as a first step to get academic justification to the Technology Acceptance Model (TAM) to determine the extent to which the information system developed acceptable stakeholders. Results from this process as a reference the development of a new information system that corresponds with institutional policy Unnes.

The individual acceptance of the use of information technology systems can be determined through technology acceptance model (TAM) (Fred D. Davis, 1986) (F. Davis, 1989) (Davis, F. D., Bagozzi, R., \& Warshaw, 1989) (Szajna, 1996).

This theory was developed from the Theory of Reasoned Action or TRA (Ajzen \& Fishbein, 1980). 
(Darsono, 2005) adds the TAM model with multiple external variables such as individual differences, and characteristics of the research system adopted (Hong, Thong, Moon, \& Tam, 2008).

Technology acceptance model is a model of acceptance of information technology systems that will be used by the user.

Individual differences (individual differences) and the characteristics of the system (system characteristics) are external variables that will affect the interest of individuals to use information technology through its ease of use perceived (perceived ease of use), perceived usefulness (perceived usefulness), and attitudes (attitudes)

Characteristics of individual differences characterized the inquiry item to establish confidence-alone computer (computer self-efficacy) were adapted from studies Harrison and Rainer (1992) and item construct knowledge of the search domain (knowledge of the search domain)

Characteristics of the system is characterized in the construct of terminology (terminology), the design of the screen (screen design), and relevant (relevance) (Hong et al., 2008).

Interest individual in using the system information obtained through the constructs of the ease of use perceived (perceived ease of use), attitudes toward behavior (attitude towards behavior) or attitude using technology (attitude towards using technology) and interest (intention), which was adapted from research Hsu et al, (2004)

Items question to form constructs adapted from items a question using Likert scale 5 Agustiani, H. (2010) stated that there are many advantages with the Sikadu among others, to see quickly the data requested in particular academic data, services for students themselves to be faster because it is connected to the Internet, efficiently because it does not need to come to campus, but enough to do at home or via the internet wherever they are unless they have a problem to be solved campus. Another advantage that the immediate value can be viewed online, meaning that students can view them online via a computer the value it has, then a student at any time to see the development of GPA and GPA and students can also see what classes can be taken further, the amount of courses that can be taken to the next semester already know without consultation prior to the academic assistant.

Agustiani, NH (2010) found the fact to the organization or Unnes overall very many benefits, among others, that the planning system studies, value, timeliness and accuracy of the test, the better collection of exam questions. With the construction of the information system that is beginning to improve a system that is prone among other leaks, 
changes and actually can be monitored on a security value includes criteria for making the course by each student. In addition to the current system running the Workload lecturer is a form that must be filled each lecturer at the beginning of each semester, it can be immediately seen that the lecturer has the burden of credit / task was already qualified or excess and so on.

With the academic application greatly affect the performance of employees and lecturers, initially implementing the system are many who oppose minded, with the later system will reduce a lot of administrative personnel so that the faculty will implement difficult and many who oppose. But once the system is implemented until now, integration was clear and focused, more employees enjoy and leadership can monitor each employee. Because of the nature of the Sikadu ease, a lot of advantages and benefits that really support the employee's duties in the service of professors, students that require an outside party. In providing the information requested or needed immediately, it could quickly without having to wait such a long time before using Sikadu. (Agustiani, $\mathrm{NH}(2010))$

Utilization sikadu significant positive effect on individual performance. This shows that the use of sikadu with high intensity can improve individual performance.

Ease of use Sikadu not moderate influence on the performance of individual Sikadu utilization, so that it can be concluded that the variable ease of use Sikadu not moderating variables. This shows that it is easy or difficult it sikadu use does not affect the use of sikadu on individual performance. (Agustiani, N.H., 2010)

Empirically found that to receive the information technology related to the implementation of Sikadu do not have to think in advance whether the benefits of information technology or not but it is a necessity and needs so that information technology should be considered easy to digunakan.Dan to the current information technology has been considered something that is easy, because it is often carried out trainings dedicated in improving the skills of information technology use by faculty, such as drills operate SPSS, made a power point, operate the internet, making email, upload teaching materials on the internet. (Palupiningdyah, et al., 2011)

Myristika, $\mathrm{N}$ and Adam, H., 2013 conduct aimed at analyzing the behavior of admissions to the use of web-based academic information system at UB by using Technology Acceptance Model (TAM). Testing the hypothesis by applying the model of TAM through an approach Structural Equation Modeling (SEM). The results show that there is significant influence on the perceived usefulness Ease of Use and Attitudes Toward Behavior perceived. Attitudes Toward Behavior positive effect on Behavioral Intention. Behavioral 
Intention positive effect on the use of the Real System. There are interesting findings which do not affect the perceived usefulness of Behavior Intention.

Hand, T., et al., 2014 analyzing the acceptance of academic information system using web-based technology acceptance model (TAM) and usability case studies on STTNAS Yogyakarta to get the assurance level of user acceptance of the application is said to be good SIAKAD (agree). Factors that influence the level of acceptance SIAKAD for variable TAM is the user's perception of the ease of (perceived ease of use) and the user's perception of the kegunaa / benefit (perceived usefulness), while the attitude of the users towards the use of (attitude toward using) does not affect the level of acceptance SIAKAD based suitability test. Usability for variables, which do not affect the level of acceptance SIAKAD is the error so that the user is still difficult to find information on a web site. Based on the resulting model can be re-proposed several steps to improve the level of acceptance of the use of online tools SIAKAD checker.

\section{Methods}

Acquisition data done by interview / in dept interview, documentation, and questionnaire. The questionnaire used was circulated in each environment to assess the potential in Unnes. Next step observations were made of the process of data entry, data processing up to printing documents. Items question to form constructs adapted from items a question using Likert scale 5

\section{Results and Discussion}

SEM is a statistical technique that is used to build and test the statistical models are usually in the form of causal models. SEM is actually a hybrid technique that includes aspects of affirmation (confirmatory) of the factor analysis, path analysis and regression (Narimawati and Sarwono, 2007). 


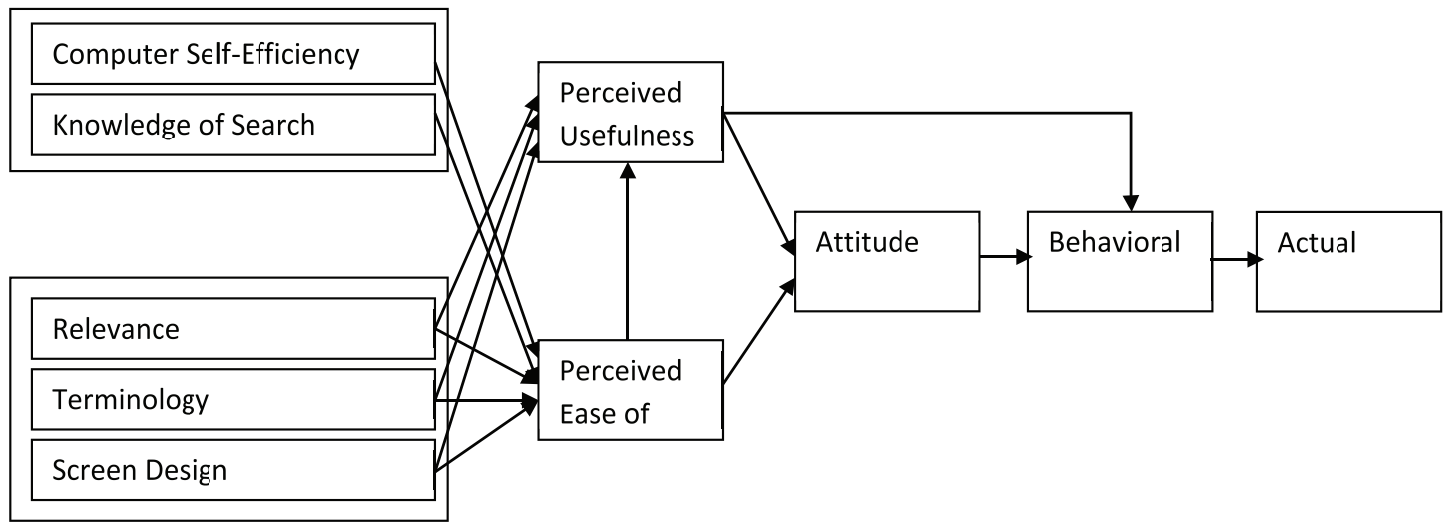

The research method was developed by distributing questionnaires to the PPS and which has been restored and declared valid. The questionnaire was filled out by 785 students (student class of 2013). Each questionnaire consisted of 152 parameters

With this TAM, it can be proposed hypothesis is as follows:

- $\mathrm{H} 1$ : Relevance will affect the Perceived Ease of Use

- H2 : Terminology will affect the Perceived Ease of Use

- H3 : Screen Design will affect the Perceived Ease of Use

- H4 : Knowledge of Search Domain will affect the Perceived Ease of Use

- H5 : Computer Self-Efficiency will affect the Perceived Ease of Use

- H6 : Relevance will affect the Perceived Usefulness

- H7 : Terminology will affect the Perceived Usefulness

- H8 : Screen Design will affect the Perceived Usefulness

- H9 : Perceived Ease of Use will affect the Perceived Usefulness

- H10: Perceived Ease of Use will affect the Attitude

- H11: Perceived Usefulness will affect the Attitude

- H12: Attitute will affect the Behavioral

- H13: Perceived Usefulness will affect the Behavioral

- H14: Behavioral will affect the Actual

The hypothesis can be formulated based on the number of relationships between independent and dependent variables that exist in the structural model and as the basis for a decision is to look at the Figures and Tables in column P (probability), namely:

- If $\mathrm{p}>0.05, \mathrm{HO}$ is rejected (no relation) 


\begin{tabular}{|c|c|c|c|c|c|c|c|c|}
\hline & & & & Estimate & S.E. & C.R. & $\mathrm{P}$ & Label \\
\hline $\mathrm{H} 1$ & PEOU & $<-$ & $\mathrm{R}$ & .586 & .194 & 3.026 & .002 & Accepted \\
\hline $\mathrm{H} 2$ & PEOU & $<-$ & $\mathrm{T}$ & .549 & .210 & 2.609 & .009 & Accepted \\
\hline $\mathrm{H} 3$ & PEOU & $<-$ & SD & .558 & .215 & 2.595 & .009 & Accepted \\
\hline $\mathrm{H} 4$ & PEOU & $<-$ & KOSD & .523 & .314 & 1.668 & .095 & Rejected \\
\hline $\mathrm{H} 5$ & PEOU & $<-$ & CSE & 1.388 & .069 & 20.182 & $* * *$ & Accepted \\
\hline $\mathrm{H} 6$ & PU & $<-$ & $\mathrm{R}$ & .333 & .118 & 2.817 & .005 & Accepted \\
\hline $\mathrm{H} 7$ & PU & $<-$ & $\mathrm{T}$ & .311 & .127 & 2.446 & .014 & Accepted \\
\hline $\mathrm{H} 8$ & PU & $<-$ & SD & .313 & .129 & 2.430 & .015 & Accepted \\
\hline $\mathrm{H} 9$ & PU & $<-$ & PEOU & .805 & .031 & 25.686 & $* * *$ & Accepted \\
\hline $\mathrm{H} 10$ & ATU & $<-$ & PEOU & .390 & .043 & 8.987 & $* * *$ & Accepted \\
\hline $\mathrm{H} 11$ & ATU & $<-$ & PU & .336 & .043 & 7.782 & $* * *$ & Accepted \\
\hline $\mathrm{H} 12$ & BIU & $<-$ & ATU & .214 & .056 & 3.834 & $* * *$ & Accepted \\
\hline $\mathrm{H} 13$ & BIU & $<-$ & PU & .389 & .043 & 9.008 & $* * *$ & Accepted \\
\hline $\mathrm{H} 14$ & AUB & $<-$ & BIU & .273 & .031 & 8.680 & *** & Accepted \\
\hline
\end{tabular}

- If $\mathrm{p}<0.05, \mathrm{HO}$ is accepted (no relation)

Based on the calculation results obtained $\frac{C_{\min }}{d f}=\frac{3849.299}{2263}=1.700$. These results indicate that the model fit the data because $\frac{C_{\min }}{d f}<2.00$.

Others obtained results based on the data above, the hypothesis $\mathrm{H} 4$ is rejected. It has meaning Knowledge of Search Domain has no effect on Perceived Ease of Use

\section{Conclusion}

Overall based on the data above, Perceived Ease of Use is strongly influenced by Relevance, Terminology, Screen Design and Computer Self-Efficiency. Perceived Usefulness is strongly influenced by Relevance, Terminology, Screen Design and Perceived Ease of Use. Attitude is very influenced by Perceived Ease of Use, and Perceived Usefulness. Behavioral influenced by attitute and Perceived Usefulness. Behavioral will affect Actual

\section{References}

[1] Agustiani, N.H.,(2010).Pengaruh Pemanfaatan Sistem Informasi Akademik Terpadu (Sikadu) Terhadap Kinerja Individual Dengan Kemudahan Penggunaan Sebagai Variabel Moderating (Tesis). Universitas Diponegoro

[2] Ajzen, l.; Fishbein, M (1980), Understanding attitudes and predicting social behavior, Englewood Cliffs, NJ: Prentice-Hall 
[3] Darsono, L. I. (2005). Examining Information Technology Acceptance. Gadjah Mada International Journal of Business, 7(2), 155-178.

[4] Davis, F. D. (1989), "Perceived usefulness, perceived ease of use, and user acceptance of information technology", MIS Quarterly, 13(3): 319-340

[5] Hardyanto. 2012. ICT and Institutional Learning: Unnes' experience Prosiding Seminar NasionalSeminar Nasional Cakrawala Pembelajaran Berkualitas di Indonesia.

[6] Harrison, A. W., \& Rainer, R. K. (1992). The influence of individual di€erences on skill in end-user computing. Journal of Management Information Systems, 9, 93 \pm 113 .

[7] Ajzen, I., \& Fishbein, M. (1980). Understanding attitudes and predicting social behaviour. Englewood Cliffs, New Jersey: Prentice-Hall. Retrieved from citeulikearticle-id:235626

[8] Darsono, L. I. (2005). Examining Information Technology Acceptance by Individual Professionals. Gadjah Mada International Journal of Business, (Vol 7, No 2 (2005): May-August). Retrieved from http://gamaijb.mmugm.ac.id/e-journal/index. php/gamaijb/article/view/162

[9] Davis, F. D., Bagozzi, R., \& Warshaw, P. (1989). User Acceptance Of Computer Technology: A Comparison Of Two Theoretical Models. Management Science, 35(8), 982-1003., 35(8), 982-1003.

[10] Davis, F. (1989). Perceived Usefulness, Perceived East of Use, and User Acceptance of Information Technology. MIS Quarterly, 13(3), 319-340. http://doi.org/10.1016/S03050483(98)00028-0

[11] Davis, F. D., Bagozzi, R. P., \& Warshaw, P. R. (1992). Extrinsic and intrinsic motivation to use computers in the workplace. Journal of Applied Social Psychology, 22(14), 1111-1132. http://doi.org/10.1111/j.1559-1816.1992.tb00945.x

[12] Fred D. Davis, J. (1986). a Technology Acceptance Model for Empirically Testing New End-User Information Systems: Theory and Results. Doctoral Dissertation, Sloan School of Management, MIT, (January 1985).

[13] Hong, S. J., Thong, J. Y. L., Moon, J. Y., \& Tam, K. Y. (2008). Understanding the behavior of mobile data services consumers. Information Systems Frontiers, 10(4), 431-445. http://doi.org/10.1007/s10796-008-9096-1

[14] Szajna, B. (1996). Empirical Evaluation of the Revised Technology Acceptance Model. Management, 42(1), 85-92. http://doi.org/10.1287/mnsc.42.1.85

[15] Hong, S.-J., Thong, J.Y.L., Moon, J.-Y., and Tam, K.-Y. "Understanding the behavior of mobile data services consumers," Information Systems Frontiers (10:4) 2008, pp 431-445. 
[16] Hsu, M.-H., and Chiu, C.-M. "Predicting electronic service continuance with a decomposed theory of planned behaviour," Behaviour \& Information Technology (23:5) 2004, pp 359 - 373.

[17] Lukito.2009. Pemanfaatan TI di Perguruan Tinggi. http://lukito.staff.ugm.ac.id/files/ 2013/02/Pemanfaatan-TI-di-Perguruan-Tinggi-Final.pdf [9 November 2013]

[18] Palupiningdyah dan Widiyanto (2011). Strategi peningkatan kualitas pembelajaran Melalui pemanfaatan increasing learning Motivation (ILMO). Dalam Jurnal "Ekplanasi Volume 6 Nomor 2 Edisi September 2011 (Online); Tersedia: http://www.kopertis6. or.id/journal/index.php/eks/article// 